\title{
PENGARUH CORPORATE SOCIAL RESPONSIBILITY DISCLOSURE TERHADAP NILAI PERUSAHAAN DENGAN PROFITABILITAS SEBAGAI VARIABEL INTERVENING PADA PERUSAHAAN SEKTOR PERTAMBANGAN YANG TERDAFTAR DI BURSA EFEK INDONESIA TAHUN 2012-2016
}

\author{
Dwi Suhartini, \\ Ira Megasyara \\ Universitas Pembangunan Nasional "Veteran" Jawa Timur \\ iramegasyara@gmail.com
}

\begin{abstract}
This research aims to test the influence of corporate social responsibility (CSR) against the company's value and profitability, as well as how the influence of corporate social responsibility disclosures of the company's profitability as an intervening variable. There are about $70 \%$ Indonesia environmental damage caused by mining operations that implement CSR programs and mining companies can reduce the environmental impact of such business. This research uses a quantitative approach to the analysis of data by the method of partial least square (PLS). Population as many as six company the mining sector listed on the effect indonesia of 2012-2016.A method of the sample collection use purpose of sampling, as many as 30 report a finance company. This research result indicates that csr not contributing to value of enterprise, but contribute to profitability. Profitability capable of being variable intervening between relations csr on the company, it means profitability high giving effect to the high value of enterprise.
\end{abstract}

Keyword: Corporate social responsibility, Value of the company, Profitability, Variable intervening

\section{PENDAHULUAN}

Perusahaan pada sektor pertambangan merupakan perusahaan yang mampu memberikan kontribusi besar terhadap berbagai aspek, mulai dari penananman modal asing (PMA), penanaman modal dalam negeri (PMDN), kegiatan ekspor, penerimaan devisa, pendapatan Negara dan produk domestic bruto (Mulyono, 2013). Perusahaan sektor pertambangan juga merupakan salah satu sektor usaha yang mampu menyerap tenaga kerja dalam jumlah besar sehingga mampu mengurangi tingginya angka pengangguran di Indonesia. Namun banyaknya peranan perusahaan sektor pertambangan tersebut tidak membuat perusahaan sektor pertambangan lepas dari masalah. Perusahaan sektor pertambangan yang dalam menjalankan kegiatan produksinya berhubungan langsung dengan sumber daya alam menimbulkan masalah - masalah terkait dengan lingkungan alam. Menurut Wahana Lingkungan Hidup Indonesia (WALHI) perusahaan sektor pertambangan memiliki kontribusi paling besar terkait dengan kerusakan alam yang ada di kawasan Indonesia (Metrosiantar.com, 20 Januari 2014).

Beberapa kasus yang dilakukan oleh perusahaan sektor pertambangan di Indonesia dan menjadi pemicu berkembangnya praktik CSR antara lain adalah peristiwa pada perusahaan pertambangan di Bengkulu. Kerusakan lingkungan hidup akibat limbah batubara di sepanjang DAS Air Bengkulu hingga pesisir pantai di Kota Bengkulu dan Bengkulu Tengah yang terjadi sejak 1980-an hingga tahun ini (2017). Masalah izin terindikasi masuk kawasan hutan konservasi dan lindung yang terungkap dalam surat Direktorat Jenderal Palonologi Kementerian Kehutanan No. S.706/VII-PKH/2014 bertanggal 10 Juli 2014 pun belum ditindaklanjuti. (Mongabay, 2017). 
Jaringan Advokasi Tambang (Jatam) memperkirakan, sekitar 70\% kerusakan lingkungan Indonesia karena operasi pertambangan. Sekitar 3,97 juta hektar kawasan lindung terancam

karena aktivitas pertambangan, termasuk keragaman hayati di sana. Tak hanya itu, daerah aliran sungai (DAS) rusak parah meningkat dalam 10 tahun terakhir. Sekitar 4.000 DAS di Indonesia, 108 diantaranya rusak parah. Dengan menerapkan program CSR perusahaan pertambangan dapat mengurangi dampak lingkungan dari usaha tersebut.

Sebagai bentuk pertanggungjawaban perusahaan akan mengeluarkan sejumlah biaya guna melaksanakan kegiatan tanggung jawab sosialnya tersebut sehingga mengurangi pendapatan dalam perusahaan. Tetapi seiring berjalannya waktu, perusahaan yang melaksanakan tanggung jawab sosial akan menghasilkan loyalitas konsumen yang lebih besar terutama dalam hal produk-produk yang bersifat ramah lingkungan, karena secara tidak langsung perusahaan menunjukkan kepada masyarakat bahwa dengan melaksanakan kegiatan CSR perusahaan ikut berperan serta dalam kelestrian lingkungan dan dapat membawa dampak positif bagi masa depan perusahaan. Jika perusahaan peduli dengan lingkungan citra perusahaan akan semakin baik. Kemudian dari citra perusahaan yang baik akan menarik para investor. Bila CSR dilaksanakan berkelanjutan dapat dijadikan sebagai strategi marketing bagi perusahaan, karena perusahaan dengan melaksanakan CSR dapat memperoleh banyak manfaat.

Rosiana (2013) meneliti tentang pengaruh pengungkapan CSR terhadap nilai perusahaan dengan profitabilitas sebagai variabel pemoderasi menunjukkan hasil bahwa pengungkapan CSR berpengaruh positif terhadap nilai perusahaan dan profitabilitas mampu memperkuat pengaruh pengungkapan CSR terhadap nilai perusahaan. Sedangkan menurut penelitian yang dilakukan oleh Handriyani (2013) menunjukkan hasil yang berbeda pada penelitian yang sebelumnya yakni adanya pengaruh signifikan antara CSR terhadap nilai perusahaan dan profitabilitass tidak dapat mempengaruhi hubungan antara pengungkapan CSR terhadap nilai perusahaan, yang berarti bahwa CSR tidak akan meningkatkan nilai perusahaan pada saat profitabilitas perusahaan tinggi.

Rumusan Masalah dalam penelitian ini adalah 1) Apakah pengungkapan CSR perusahaan berpengaruh terhadap nilai perusahaan? 2) Apakah pengungkapan CSR perusahaan berpengaruh terhadap profitabilitas? 3) Apakah profitabilitas berpengaruh terhadap nilai perusahaan? 4) Apakah CSR berpengaruh terhadap nilai perusahaan melalui profitabilitas?.

Tujuan dalam penelitian ini adalah Untuk menguji dan menganalisis pengaruh pengungkapan CSR perusahaan terhadap nilai perusahaan. Untuk menguji dan menganalisis pengaruh pengungkapan CSR perusahaan terhadap profitabilitas. Untuk menguji dan menganalisis pengaruh profitabilitas terhadap nilai perusahaan. Untuk menguji dan menganalisis pengaruh CSR terhadap nilai perusahaan melalui profitabilitas.

\section{TINJAUAN PUSTAKA DAN PENGEMBANGAN HIPOTESIS 2.1 Konsep Tripel Bottom Line}

Istilah tripel bottom line pertama kali dikemukakan oleh Elkington (1997) dalam bukunya cannibal wirh fork: The Tripel Bottom Line of 21st Century Business. Konsep ini merumuskan bahwa kelangsungan dan pertumbuhan perusahaan tidak hanya bergantung pada laba (profit), namun harus ada tindakan yang dilakukan perusahaan terhadap lingkungan (planet), dan keadilan untuk masyarakat dalam maupun luar perusahaan (people). Tujuan akhir tersebut diantaranya adalah menyeimbangkan antara kinerja ekonomi, kesejahteraan sosial (well being), dan peremajaan serta pelestarian lingkungan hidup.

\subsection{Legitimacy Theory}

Teori legitimasi menjelaskan bahwa setiap perusahaan atau organisasi berhubungan erat dengan masyarakat sehingga perusahaan harus patuh pada norma-norma dalam sosial masyarakat karena jika perusahaan menjalankan operasinya sesuai dengan norma sosial akan membuat perusahaan semakin legitimate. Teori ini berfokus pada hubungan antara perusahaan atau organisasi dengan masyarakat. Deegan et al (2002) menyatakan bahwa jika terdapat kesamaan antara hasil dan harapan masyarakat terhadap perusahaan, maka perusahaan tersebut dapat dikatakan legitimate, karena dengan adanya kesamaan tersebut masyarakat tidak akan menuntut perusahaan. 


\subsection{Stakeholder Theory}

Standford Research Institute (SRI) pada tahun 1963 memperkenalkan istilah stakeholder untuk pertama kalinya (Freeman, 1983:31). Teori stakeholder menyatakan bahwa seharusnya dalam kegiatan operasional perusahaan tidak hanya berfokus pada pencapaian tujuan namun juga harus memperhatikan kepentingan stakeholder terkait dan memberikan manfaat. Hal tersebut menunjukkan bahwa dukungan stakeholder dapat mempengaruhi keberadaan suatu perusahaan (Ghozali dan Chariri, 2007). Individu, kelompok atau komunitas, dan masyarakat jika memiliki pengaruh, kekuasaan, dan kepentingan terhadap perusahaan juga dapat dikatakan segabagai stakeholder (Budiman et al, 2008).

\subsection{Pengungkapan Corporate Social Responsibility}

Undang-Undang No.40 Tahun 2007 pasal 66 ayat (2) tentang Perseroan Terbatas berisi mengenai kewajiban perusahaan dalam mengungkapkan atau melaporkan pelaksanaan tanggung jawab sosial dalam laporan tahunan. Undang- Undang ini didukung oleh Peraturan BAPEPAM NOMOR X.K.6 tentang penyampaian laporan emiten atau perusahaan publik yang ditetapkan pada 1 Agustus 2012.

Indeks Global Reporting Iniative (GRI) adalah sebuah organisasi non-profit yang mempromosikan keberlanjutan ekonomi suatu perusahaan dan menghasilkan standar umum untuk pelaporan keberlanjutan di dunia yang juga dikenal sebagai tanggung jawab pelaporan sosial perusahaan (CSR). Kinerja GRI menjelaskan indikator dalam pengungkapan CSR dibagi dalam tiga aspek utama yaitu, indikator kinerja ekonomi, lingkungan, dan sosial.

\subsection{Nilai Perusahaan}

Nilai perusahaan adalah kemampuan manajerial dalam meningkatkan kinerja perusahaan yang ditandai dengan pertumbuhan yang terus menerus, pereduksian biaya-biaya, menciptakan nilai pada merek, menciptakan nilai bagi pelanggannya, dan mengkomunikasikan keberhasilannya bagi para investor untuk mendapatkan investasi yang lebih menguntungkan bagi perusahaan (Daum, 2003).

\subsection{Profitabilitas}

Menurut Fahmi (2013:135) rasio profitabilitas digunakan untuk mengukur efektivitas manajemen secara keseluruhan yang ditujukan oleh besar kecilnya tingkat keuntungan yang diperoleh dalam hubungannya dengan penjualan maupun investasi. Semakin baik rasio profitabilitas menggambarkan semakin baik kemampuan tingginya perolehan keuntungan perusahaan.

\subsection{Ecconomic Value Added (EVA)}

Metode EVA pertama kali dikembangkan oleh Stewart \& Stern seorang analis keuangan dari perusahaan Stern Stewart \& Co pada tahun 1993. Model EVA menawarkan parameter yang cukup objektif karena berangkat dari konsep biaya modal (cost of capital) yakni mengurangi laba dengan beban biaya modal, dimana beban biaya modal ini mencerminkan tingkat resiko perusahaan. Beban biaya modal ini juga mencerminkan tingkat kompensasi atau return yang diharapkan investor atas sejumlah investasi yang ditanamkan di perusahaan. Hasil perhitungan EVA yang positif merefleksikan tingkat return yang lebih tinggi daripada tingkat biaya modal. 


\subsection{Model Riset}

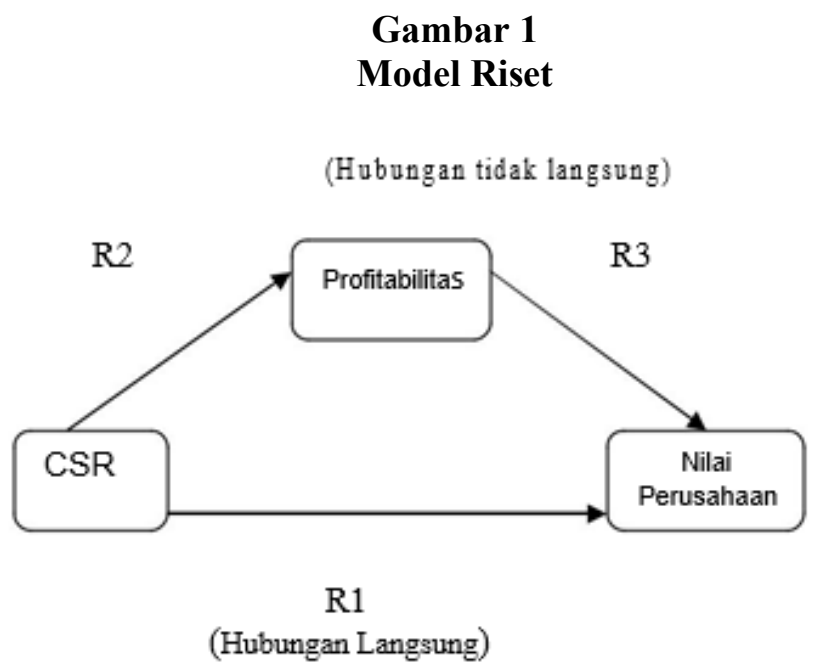

Model riset memberikan penjelasan hubungan kausalitas antar variabel berdasarkan pada teori. Anak panah menunjukkan hubungan antar variabel. Model bergerak dari kiri ke kanan dengan implikasi prioritas hubungan kausal variabel yang dekat ke sebelah kiri. Berdasarkan gambar model riset diajukan hubungan berdasarkan teori bahwa CSR mempunyai hubungan langsung dengan nilai perusahaan (R1). Namun demikian CSR juga mempunyai hubungan tidak langsung ke nilai perusahaan yaitu dari CSR ke profitabilitas (R2) baru kemudian ke nilai perusahaan (R3).

\subsection{Pengembangan Hipotesis \\ 2.9.1.Pengaruh Pengungkapan CSR terhadap Nilai Perusahaan}

Hasil penelitan Andayani (2015) menunjukkan CSR berpengaruh positif terhadap nilai perusahaan dengan arah koefisien positif. Tujuan utama perusahaan dalam menjalankan operasionalnya adalah untuk meningkatkan nilai perusahaaan. Nilai perusahaan akan tumbuh secara berkelanjutan (sustainable) apabila perusahaan memperhatikan dimensi ekonomi, sosial dan lingkungan hidup karena keberlanjutan merupakan keseimbangan antara kepentingan-kepentingan ekonomi, lingkungan dan masyarakat. Dimensi tersebut terdapat di dalam penerapan Corporate Social Responsibility yang dilakukan perusahaan sebagai bentuk pertanggungjawaban dan kepedulian terhadap lingkungan di sekitar perusahaan. Berdasarkan uraian di atas, maka hipotesis yang dibangun dalam penelitian ini adalah :

H1 : Terdapat pengaruh pengungkapan CSR terhadap nilai perusahaan.

\subsubsection{Pengaruh Pengungkapan CSR terhadap Profitabilitas}

Menurut Panjaitan (2015) pengungkapan CSR terhadap profitabilitas dapat mengindikasikan bahwa apabila perusahaan melakukan tanggungjawab sosial terhadap lingkungan sekitarnya maka dalam jangka panjang akan membawa dampak positif yang tercermin pada keuntungan perusahaan dan peningkatan kinerja keuangan. Beberapa dampak positif yang dapat terlihat adalah seperti meningkatnya akuntabilitas perusahaan, membuat citra perusahaan menjadi lebih baik di depan mata masyarakat umum, meminimalkan resiko, dan sebagai alat analisis bagi investor dan kreditor. Sehingga, hal ini dapat memicu perusahaan untuk lebih lagi meningkatkan kesadaran untuk melakukan aktivitas corporate social responsibility dan pengungkapannya.

H2 : Terdapat pengaruh pengungkapan CSR terhadap profitabilitas.

\subsubsection{Pengaruh Profitabilitas terhadap Nilai Perusahaan}

Kamil dan Herusetya (2012) berpendapat bahwa tingkat profitabilitas yang semakin besar menunjukkan perusahaan mampu mendapatkan laba yang semakin besar, sehingga perusahaan mampu untuk meningkatkan aktivitas tanggung jawab sosial, serta mengungkapkan tanggung jawab sosialnya dalam laporan tahunan dengan lebih luas. Profitabilitas merupakan salah satu bagian finansial yang 
berpengaruh terhadap nilai perusahaan. Profitabilitas menunjukkan tingkat keuntungan bersih yang mampu diraih oleh perusahaan saat menjalankan operasinya. Semakin besar keuntungan yang diperoleh semakin besar kemampuan perusahaan untuk membayarakan devidennya, sehingga akan semakin banyak investor yang berinvestasi pada perusahaan tersebut. Berdasarkan uraian di atas, maka hipotesis yang dibangun dalam penelitian ini adalah :

H3 : Terdapat pengaruh profitabilitas terhadap nilai perusahaan.

\subsubsection{Pengaruh Pengungkapan CSR terhadap Nilai Perusahaan dengan Profitabilitas sebagai Variabel Intervening}

Menurut Kusumadilaga (2010), nilai perusahaan akan dapat bertumbuh secara berkelanjutan apabila perusahaan dapat memperhatikan dimensi ekonomi, sosial, dan lingkungan. Ketiga dimensi tersebut dapat dicapai melalui penerapan Corporate Social Responsibility sebagai wujud pertanggungjawaban perusahaan terhadap keseimbangan lingkungan disekitarnya serta peningkatan kesejahteraan stakeholder.

Semakin baik kinerja yang dilakukan perusahaan didalam memperbaiki lingkungannya (kinerja ekonomi, lingkungan dan sosial), maka nilai perusahaan semakin meningkat sebagai akibat dari para investor yang menanamkan sahamnya pada perusahaan. Berdasarkan uraian di atas, maka hipotesis yang dibangun dalam penelitian ini adalah:

H4 : Terdapat pengaruh pengungkapan CSR terhadap nilai perusahaan melalui profitabilitas.

\section{METODE PENELITIAN}

\subsection{Jenis Penelitian}

Penelitian ini menggunakan pendekatan kuantitatif. Tujuan penggunaan pendekatan penelitian tersebut adalah menguji tingkat pengaruh atau hubungan antara variabel - variabel yang dihasilkan dalam bentuk angka, dengan mengumpulkan data sebagai faktor pendukung dan dianalisis menggunakan alat penguji yang sesuai dengan variabel - variabel yang digunakan dalam penelitian.

\subsection{Definisi Operasional}

Nilai Perusahaan sebagai variabel dependen dalam penelitian diukur menggunakan Tobin's q. Tobin's q menunjukkan bahwa perusahaan tidak terfokus pada investor dalam bentuk saham saja (Sukamulja, 2004 dalam Permanasari, 2010). Tobin's q dirumuskan sebagai berikut:

$$
\text { Tobins' } \mathrm{Q}=((\mathrm{EMV}+\mathrm{D})) /((\mathrm{EBV}+\mathrm{D}))
$$

Keterangan :

Tobins' $\mathrm{Q}=$ Nilai perusahaan

EMV $=$ Closing Price $\mathrm{x}$ jumlah saham beredar

EBV $\quad=$ Nilai buku total ekuitas

$\mathrm{D} \quad \quad=$ Nilai buku total hutang

\section{Pengungkapan CSR}

Variabel independen diukur dengan mengacu pada pengungkapan CSR dalam laporan tahunan perusahaan kemudian dilakukan check menggunakan 79 item pengungkapan yang diterbitkan oleh GRI (Global Reporting Index). Pada variabel ini dilakukan peneliti dengan mengukur pengungkapan CSR menggunakan rumus sebagai berikut (panjaitan 2015):

$\mathrm{CSRDI}=($ Jumlah item yang diungkapkan perusahaan $) /($ Jumlah yang seharusnya diungkapkan $(79$ item) ) $\mathrm{x} 100 \%$

\section{Profitabilitas}

Variabel intervening dalam penelitian ini adalah profitabilitas yang diproksi dengan Economic Value Added (EVA). Rumus yang digunakan untuk menghitung EVA (Martin dan petty 2000:8 dalam Maya Sari 2006) adalah sebagai berikut : 
$\mathrm{EVA}=\mathrm{NOPAT}-\left(\mathrm{c}^{*} \mathrm{x}\right.$ Capital $)=\mathrm{EBIT}-\mathrm{TAX}-(\mathrm{WACC} \times$ Capital $)$

Dimana :

EVA $=$ Keuntungan operasional setelah pajak dikurangi dengan biaya modal.

NOPAT $=$ Laba operasi bersih setelah pajak

C* $\quad=$ Cost of capital yaitu ongkos modal baik dari modal berupa hutang maupun modal berupa saham. Dalam hal ini C.O.C merupakan nilai dari WACC.

Capital = Jumlah dana yang terdiri dari hutang berbunga dan ekuitas saham yang tersedia diperusahaan untuk mendanai usaha perusahaan.

EBIT = Laba perusahaan sebelum dampak pembiayaan dan perpajakan.

TAX = Besarnya pajak yang harus dibayar perusahaan.

\subsection{Jenis dan Sumber Data}

Sumber data yang digunakan dalam penelitian ini berupa data sekunder. Data diambil dari beberapa sumber, yaitu : 1). Laporan keuangan perusahaan sektor pertambangan yang terdaftar di Bursa Efek Indonesia periode 2012 - 2016 yang diunduh dari www.idx.co.id. 2). Laporan tahunan perusahaan manufaktur yang terdaftar di Bursa Efek Indonesia periode 2012 - 2016 yang diunduh dari www.idx.co.id untuk menghitung luas pengungkapan.

\subsection{Populasi dan Sampel}

Populasi pada penelitian ini adalah laporan keuangan perusahaan Manufaktur yang terdaftar di BEI periode tahun 2012 hingga tahun 2016. Penarikan sampel dalam penelitian ini dilakukan dengan menggunakan metode purposive sampling (Sugiyono, 2004:78). Adapun kriteria penarikan sampel yang ditentukan oleh peneliti yaitu : (1) Perusahaan sektor pertambangan yang terdaftar di Bursa Efek Indonesia selama periode 2012-2016. (2) Laporan CSR yang terbaru dan terlengkap 20122016. (3) Laporan keuangan perusahaan sektor pertambangan tahun 2012-2016. (4) Perusahaan sektor pertambangan yang menggunakan mata uang rupiah.(5) Laporan keuangan yang menunjukkan laba tahun 2012-2016.

\subsection{Teknik Analisis}

Dalam penelitian ini analisis data menggunakan pendekatan Partial Least Square (PLS). PLS adalah model persamaan Structural Equation Modeling (SEM) yang berbasis komponen atau varian. Menurut Ghozali (2015:5) Partial Least Square merupakan metode analisis yang powerfull, karena tidak didasarkan pada banyak asumsi OLS (Ordinary Least Squares) regresi, misalnya, data harus terdistribusi normal secara multivariate dan tidak adanya masalah multikolonieritas antar variabel eksogen. Model formalnya mendefinisikan variabel laten adalah linear agregat dari indikator-indikatornya. Weight estimate untuk menciptakan komponen skor variabel laten didapat berdasarkan bagaimana inner model (model struktural yang menghubungkan antar variabel laten) dan outer model (model pengukuran yaitu hubungan antara indikator dengan konstruknya) dispesifikasi. Hasilnya adalah residual variance dari variabel dependen. Pada penelitian ini menggunakan metode SEM-PLS dengan software Warp-PLS.

\section{HASIL DAN PEMBAHASAN}

\subsection{Hasil Uji Outer Mode (Measurement Model)}

Berdasarkan hasil output pengolahan data pada tabel 1 cross loading sebagai berikut:

Tabel 1

Combined loadings and cross-loadings

\begin{tabular}{|c|c|c|c|c|c|c|}
\hline & Nilai & Profit & CSR & Type (a & $\mathrm{SE}$ & P Value \\
\hline TOBI & 1 & 0 & & Reflect & 0.111 & $<0.001$ \\
\hline EVA & 0 & 1 & 0 & Reflect & 0.111 & $<0.001$ \\
\hline CSR & 0 & 0 & & Reflect & 0.111 & $<0.001$ \\
\hline
\end{tabular}


Hasil loading factor memenuhi syarat dengan nilai (1),(1), dan (1).Ukuran reflektif dikatakan tinggi jika berkorelasi lebih dari 0,70 dengan konstruk yang ingin diukur. Namun demikian untuk penelitian tahap awal dari pengembangan skala pengukuran nilai loading 0,5 sampai 0,60 dianggap cukup (Chin, 1998 dalam Ghozali, 2006:74).

\subsection{Convergent Validity}

Validitas konvergen berhubungan dengan prinsip bahwa pemgukuran-pengukuran dari sebuah konstruk seharusnya berkorelasi tinggi. Berikut adalah hasil output pengolahan data outer loadings :

Tabel 2

\section{Convergent Validity}

\begin{tabular}{llr}
\hline Variabel & Proksi & Validity \\
\hline X1 & CSR & 1,000 \\
Y1 & Tobin's q & 1,000 \\
Y2 & EVA & 1,000 \\
\hline
\end{tabular}

Berdasarkan tabel 2 masing-masing mempunyai nilai validity 1, yang menunjukkan bahwa masingmasing proksi merupakan variabel manifest dari masing-masing variabel laten sesuai dengan (Chin, 1998: Imam Ghozali, 2006).

\subsection{Composite Reliability}

Uji reliabilitas dapat digunakan untuk mengukur konsistensi internal alat ukur. Tabel 3 menunjukkan hasil output pengolahan data construct reliability and validity sebagai berikut:

Tabel 3

Composite Reliability

\begin{tabular}{lcc}
\hline Variabel & Cronbach's Alpha & Composite Reliability \\
\hline CSR & 1,000 & 1,000 \\
EVA & 1,000 & 1,000 \\
Nilai & 1,000 & 1,000 \\
\hline
\end{tabular}

Tabel 3 menunjukkan bahwa composite reliability untuk setiap variabel mendapat nilai 1.000 selain itu Cronbach's Alpha untuk setiap variabel penelitian ini juga bernilai 1.000, sehingga dapat disimpulkan bahwa seluruh variabel reliable.

\subsection{Hasil Uji Inner Model (Pengujian Model Struktural)}

\section{R-squared Coefficents}

Nilai R2 digunakan untuk mengukur tingkat variasi perubahan variabel independen terhadap dependen. Berdasarkan hasil pengolahan data maka hasil R-square adalah sebagai berikut :

Tabel 4 Hasil Uji R-squared Coefficents

\begin{tabular}{ll}
\hline Variabel & R Square \\
\hline Nilai & 0.668 \\
Profitabilitas & 0.457 \\
\hline
\end{tabular}

Berdasarkan tabel 4. diperoleh angka R2 (R-square) pada nilai perusahaan sebesar 0.668 atau $66,8 \%$. Hal ini menunjukkan bahwa presentase pengaruh variabel independen (CSR) terhadap variabel dependen (Nilai perusahaan) sebesar $66,8 \%$ sedangkan prosentase pengaruh variabel independen (CSR) terhadap variabel dependen (profitabilitas) sebesar 45,7\% sedangkan sisanya sebesar $54,3 \%$ dipengaruhi atau dijelaskan oleh variabel lain yang tidak dimasukkan dalam model penelitian ini. 


\section{Hasil Uji Path Coefficents (Direct Effect)}

Efek langsung (direct effect) adalah koefisien dari garis dengan anak panah satu ujung danterjadi pada dua konstruk yang dituju dengan garis anak panah satu arah. Berikut adalah hasil pengolahan data path coefficients dan p-values:

Tabel 5

Path Coefficents and $P$ values

\begin{tabular}{ccc}
\hline & Path Coefficients & P Values \\
\hline CSR $>$ Nilai Perusahaan & 0.15 & 0.192 \\
CSR $>$ Profit & 0.676 & $<0.001$ \\
Profit $>$ Nilai perusahaan & 0.697 & $<0.001$ \\
\hline
\end{tabular}

3. Hasil Uji Path Coefficients (Indirect Effect)

Efek tidak langsung adalah efek yang muncul melalui sebuah variabel antara dan terjadi pada dua konstruk yang tidak dituju dengan garis anak panah satu arah. Berikut adalah hasil output pengolahan data indirect effect:

Tabel 6

Path Coefficents and $P$ values

\begin{tabular}{lcr}
\hline & Path Coefficients & P Values \\
\hline $\begin{array}{l}\text { CSR->Nilai perusahaan } \\
\text { melalui profitabilitas }\end{array}$ & 0.472 & $<0.001$ \\
\hline
\end{tabular}

Berdasarkan tabel di atas dapat diketahui bahwa terdapat pengaruh tidak langsung CSR terhadap nilai perusahaan melalui profitabilitas dan nilai $\mathrm{P}$-value $<0.001$ yang artinya terdapat pengaruh CSR terhadap nilai perusahaan melalui profitabilitas.

\section{Total effect}

Total effect merupakan efek dari berbagai hubungan, yaitu gabungan antara efek langsung dan tidak langsung. Berikut adalah hasil output pengolahan data dari masing-masing variabel:

Tabel 7

Total Effect

\begin{tabular}{llll}
\hline & Nilai perusahaan & Profit & CSR \\
\hline Nilai Perusahaan & & 0.697 & 0.621 \\
Profit & & 0.676 \\
CSR & & \\
\hline
\end{tabular}

Berdasarkan analisis uji statistik terhadap hipotesis yang diajukan,maka rangkumannya dapat ditampilkan pada tabel 8: 
Tabel 8

Rangkuman Hasil Hipotesis

\begin{tabular}{|l|l|l|l|}
\hline No. & Hipotesis & Sig. & Keputusan \\
\hline 1. & $\begin{array}{l}\text { Pengungkapan CSR berpengaruh terhadap nilai } \\
\text { perusahaan }\end{array}$ & 0.192 & Tidak didukung \\
\hline 2. & $\begin{array}{l}\text { Pengungkapan CSR berpengaruh terhadap } \\
\text { profitabilitas }\end{array}$ & $<0.001$ & Di dukung \\
\hline 3. & $\begin{array}{l}\text { Profitabilitas berpengaruh terhadap nilai } \\
\text { perusahaan }\end{array}$ & $<0.001$ & Di dukung \\
\hline 4 & $\begin{array}{l}\text { Pengungkapan CSR berpengaruh terhadap nilai } \\
\text { perusahaan melalui profitabilitas }\end{array}$ & $<0.001$ & Di dukung \\
\hline
\end{tabular}

\subsection{Pengujian Hipotesis}

Berdasarkan hasil pengujian hipotesis data anlisis maka hipotesis dapat dijelaskan sebagai berikut:

\section{Pengaruh Pengungkapan CSR terhadap Nilai Perusahaan}

Tabel 5. menunjukkan bahwa pengaruh CSR terhadap Nilai perusahaan adalah sebesar 0.150 dengan nilai P-value sebesar 0.192>0.05, yang artinya CSR tidak berpengaruh terhadap nilai perusahaan. Hasil penelitian ini menunjukkan bahwa besar kecilnya luas pengungkapan CSR yang dilaksanakan oleh perusahaan tidakmempengaruhi peningkatan nilai perusahaan.

Sebagian besar perusahaan publik hanya berfokus pada faktor keuangan, perusahaan kurang berfokus pada faktor -faktor non keuangan semisal CSR. Hal ini dapat terlihat pada kecilnya nilai pengungkapan CSR dari perusahaan, sehingga ketika pengungkapan dilakukan ataupun tidak oleh perusahaan tidak akan berdampak pada nilai perusahaan walaupun nilai perusahaan dapat dilihat harga saham akan tetapi investor akan melihat kondisi profitabilitas perusahaan tersebut. Jika kondisi profitabilitas rendah namun CSR yang diungkapkan tinggi, investor akan lebih memilih profitabiltas perusahaan yang tinggi dengan pengungkapan CSR yang rendah karena profitabilitas dapat melihat kondisi bagaimana perusahaan tersebut dalam meningkatkan kinerja keuangannya.

\section{Pengaruh Pengungkapan CSR terhadap Profitabilitas}

Berdasarkan tabel 5 menunjukkan bahwa pengaruh CSR terhadap profitabilitas adalah sebesar 0.676 dengan nilai $\mathrm{P}$-value sebesar $0.001<0.05$, yang artinya terdapat pengaruh CSR terhadap profitabilitas, yang berarti bahwa tinggi atau rendahnya CSR mempengaruhi profitabilitas. Melalui program CSR perusahaan dapat mengajak masyarakat untuk melakukan daur ulang untuk limbah produksi yang dapat memberikan manfaat ekonomis bagi masyarakat. Dengan menerapkan program CSR, perusahaan juga akan mendapatkan manfaat salah satunya yaitu nama perusahaan akan lebih dikenal oleh masyarakat sebagai perusahaan yang sering melakukan aktivitas sosial yang berarti bahwa perusahaan peduli terhadap lingkungan sekitar. Sehingga produk yang dihasilkan dari perusahaan akan lebih terkenal dan di minati oleh masyarakat, akibatnya perusahaan akan memanfaatkan aset semaksimal mungkin untuk menghasilkan produk yang di minati oleh masyarakat sehingga dapatmeningkatkanprofitabilitasperusahaan.

\section{Pengaruh Profitabilitas terhadap Nilai Perusahaan}

Berdasarkan tabel 4.9 menunjukkan bahwa pengaruh profitabilitas sebesar dengan nilai Pvalue sebesr $0.001<0.05$, yang artinya terdapat pengaruh profitbilitas terhadap nilai perusahaan. Ini berarti bahwa investor sangat memperhatikan nilai tambah yang dihasilkan oleh perusahaan sehingga akan mempengaruhi nilai perusahaan dimata investor. Hasil pengujian ini sesuai dengan teori yang dinyatakan oleh Tandelilin (2007), yang mengatakan EVA adalah ukuran keberhasilan manajemen perusahaan dalam meningkatkan nilai tambah (value added) bagi perusahaan. Asumsinya adalah bahwa kinerja manajemen baik/efektif (dilihat dari besarnya nilai tambah yang diberikan), maka akan tercermin pada peningkatan nilai perusahaan yang tercermin dari harga saham perusahaan dan tingkat kembalian bagi investor. 


\section{Pengaruh Pengungkapan CSR terhadap Nilai Perusahaan Dengan Profitabilitas sebagai Variabel Intervening}

Hasil penelitian menunjukkan bahwa profitabilitas mampu menjadi variabel intervening. Hal ini ditunjukkan dengan nilai $\mathrm{t}$ penelitian $=5,4096$ lebih besar dari $\mathrm{t}$ tabel dengan tingkat signifikansi 0,05 yaitu sebesar 2,045 dan signifikasi $<0,001$. Hal ini mengindikasikan bahwa profitabilitas sebagai variabel intervening dapat meningkatkan nilai perusahaan pada saat pengungkapan corporate social responsibility yang dilakukan oleh perusahaan. Sebenarnya, pada kondisi real ada beberapa perusahaan yang menunda mengalokasikan dana untuk melakukan CSR karena likuiditas yang dimiliki oleh perusahaan tersebut rendah, hal tersebut dikarenakan banyak dana yang teralokasi pada hutang ataupun persediaan, sehingga perusahaan kesulitan untuk mengalokasikan dana untuk CSR. Oleh sebab itu, profitabilitas disini mampu memediasi

CSR terhadap nilai perusahaan karena profitabilitas berhubungan langsung dengan nilai pasar sebuah perusahaan.

Hasil peneltian ini menerima teori legetimasi O'Donovan (2002), teori legitimasi merupakan salah satu teori yang mendasari perusahaan sektor pertambangan untuk melakukan tanggung jawab sosial (Corporate Social Responsibility). Upaya perusahaan sektor pertambangan dalam bertanggung jawab secara sosial kepada lingkungan sekitarnya, dilakukan untuk mendapatkan nilai atau respon positif dari investor dan legitimasi dari masyarakat, sehingga produk-produk perusahaan sektor pertambangan lebih dikenal oleh masyarakat luas, dan menjadikan reputasi perusahaan sektor pertambangan menjadi lebih baik, sehingga perusahaan sektor pertambangan dapat memperoleh pintu masuk untuk memperoleh keuntungan yang berdampak langsung pada peningkatan profitabilitas perusahaan sektor pertambangan, dan secara otomatis juga akan meningkatkan nilai perusahan di mata investor.

Dari keseluruhan uji telah dilakukan, maka diperoleh diagram Partial Least Square sebagai berikut:

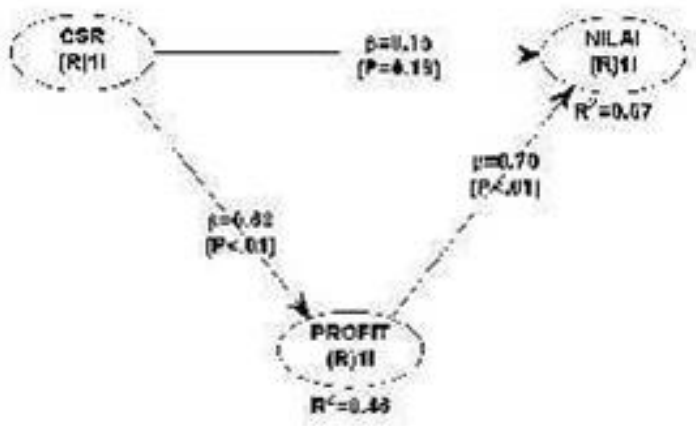

\section{SIMPULAN DAN SARAN \\ 5.1 Simpulan}

Berdasarkan analisis hasil penelitian dan pembahasan yang telah diuraikan sebelumnya dapat ditarik kesimpulan bahwa Corporate Social Responsibility (CSR) tidak memiliki kontribusi dalam nilai perusahaan pertambangan di Indonesia. CSR mampu meningkatkan nilai perusahaan apabila profitabilitas yang dilihat dari EVA mengalami peningkatan. Karena EVA menghubungkan laba dengan jumlah sumber-sumber daya yang diperlukan untuk mencapainya. Program CSR yang dilakukan secara konsisten oleh perusahaan memberikan dampak value ke masyarakat dan mendapat nilai positif untuk perusahaan, sehingga dapat meningkatkan profitabilitas perusahaan yang secara tidak langsung membuat nilai perusahaan mengalami peningkatan.

Meskipun peneliti telah berusaha merancang dan mengembangkan penelitian sedemikian rupa, namun masih terdapat keterbatasan dalam penelitian ini yaitu: Tahun dalam penelitian kurang panjang sehingga hanya mendapatkan sampel 30 laporan keuangan. Penelitian ini hanya sebatas pada perusahaan sektor pertambangan yang terdaftar di BEI. 
Implikasi hasil dari penelitian ini dalam manajerial perusahaan diharapkan lebih memperhatikan pelaksanaan tanggung jawab sosial dan lingkungan sebagai wujud tanggungjawab perusahaan terhadap masyarakat serta sebagai bentuk jaminan bagi stakeholders atas keterpenuhan berbagai harapan yang mereka inginkan. Karena CSR memberikan manfaat jangka panjang bagi perusahaan dan masyarakat.

\subsection{Saran}

Berdasarkan kesimpulan serta keterbatasan yang telah diuraikan sebelumnya maka saran yang dapat diberikan adalah: Penelitian selanjutnya dapat melakukan penelitian lebih lanjut pada sektor perbankan, farmasi ataupun food and beverage. Bagi pemakai informasi keuangan atau calon investor tidak hanya melihat pengungkapan CSR karena tidak terbukti dapat berkontribusi dalam nilai perusahaan akan tetapi dengan melihat kondisi kinerja perusahaan melalui profitabilitas, khususnya melalui rasio EVA.

\section{DAFTAR PUSTAKA}

Deegan, C. 2002. Financial Accounting Theory. McGraw-Hill Book Company: Sydney.

Elkington, J. (1997). Cannibal with Forks, the Tripple Bottom Line of TwentiethCentury Business. London: Capstone Publishing Ltd.

Fahmi, Irham. 2013. Analisis Laporan Keuangan. Bandung: Alfabeta.

Freeman, R. Edward. 1983. Stockholders and Stakeholders: A New Perspective on Corporate Governance. California Management Review. ABI/INFORM Global pg. 8.

Ghozali, Imam. (2015). Partial Least Squares Konsep, Teknik Dan Aplikasi Menggunakan Program SmartPLS 3.0, Edisi 2. Semarang: Badan Penerbit Undip.

Ghozali dan Chariri. (2007). Teori Akuntansi. Semarang: Badan Penerbit Undip

Harmoni, ati dan Andriyani, ade. 2008.Pengungkapan Corporate Social Responsibility (Csr) Pada Official Website Perusahaan Studi Pada Pt. Unilever Indonesia Tbk. Seminar Ilmiah Nasional Komputer dan Sistem Intelijen (KOMMIT 2008) Auditorium Universitas Gunadarma, . ISSN : 1411-6286.

Kamil, Ahmad dan Antonius Herusetya. 2012. Pengaruh Karakteristik Perusahaan Terhadap Luas Pengungkapan Kegiatan Corporate Social Responsibility. Media Riset Akuntansi Vol. 2 No. 1.

Listianto, G. Anto, 2003, " EVA: An Alternative of Financial Performance Measurement”, Jurnal FOKUS Ekonomi. Vol.1.No. 3. Desember: hal. 244-254.

Metro Siantar. 2014. Perusahaan Pertambangan Paling Merusak Lingkungan. Jakarta http://www.metrosiantar.com/perusahaan-pertambangan-paling-merusak-lingkungan/. Diakses 17 Juli 2017

Mulyono, Kasan. 2013. Peran Industri Tambang bagi Perekonomian.http://ekonomi.kompasiana.com/bisnis/2013/03/07/peran-industri tambang-bagiperekonomian-539991. html. Diakses pada 17 Juli 2017

Panjaitan, Manangar Julianto. 2015. Pengaruh Tanggungjawab Sosial Perusahaan Terhadap Nilai Perusahaan Dengan Profitabilitas Sebagai Variabel Intervening Dan Moderating. Jurnal Tekun.Volume VI, No. 01, hal 54-81.

Rosiana, G.A Made Ervina, Juliarsa, Gede dan Sari, Maria M. Ratna. (2013) "Pengaruh Pengungkapan CSR Terhadap Nilai Perusahaan dengan Profitabilitas Sebagai Variabel Pemoderasi”. E-Jurnal Akuntansi Universitas Udayana, Vol. 5 No. 3, hal. 723-738.

Sari maya. 2006 . Menciptakan Nilai dengan EVA. Jurnal ekonomi. Vol.68. Edisi Agustus. 
Stewart, Stern. 1993. Economic Value Added. www.sternstewart.com

Sugiyono. (2013). Metode Penelitian Kuantitatif Kualitatif dan R \& D. Bandung: Alfabeta.

Undang-undang No 40. (2007). Tentang Perseroan Terbatas.

http://www.mongabay.co.id/2017/05/17/kerusakan-lingkungan-akibat-tambang-batubara-terusberlanjut-apa-solusinya/. Diakses 15 Agustus 2017

www.idx.com 